\title{
CHARACTERISTICS OF SURFACE RUNOFF FOR FOUR VEGETATION TYPES IN SMALL WATERSHED OF NVER ZHAI IN WEST HUNAN, CHINA
}

\author{
Jia Luo ${ }^{1}$, YongQiang LiU ${ }^{2}$, XUAN Y Y ${ }^{2}$, YuXIN TIAN ${ }^{1}$, \\ XiaOling Zhou ${ }^{1}$ and Longsheng Chen* \\ Hunan Forestry Academy, Changsha, Hunan 410004, China
}

Key words: Vegetation type, Surface runoff, Small watershed, Runoff coefficient

\begin{abstract}
Characteristics of the surface runoff of four vegetation types in the small watershed of Nver Zhai, Wuling Mountain Area, West Hunan were studied. Results indicated that, from June 10, 2015 to September 10, 2016 the precipitation recorded was up to $1971.80 \mathrm{~mm}$, and there occurred 83 rainfalls during the period of investigation. With the increase in the rainfall, the surface runoff gradually increased, among which the Eucommia ulmoides Oliv. plantation showed significantly high runoff. When the rainfall gradually increased to $30 \mathrm{~mm}$, the surface runoff was highest for the sloping farmland. Under an intense rainfall $>50 \mathrm{~mm}$, there was a significant augmentation in the surface runoff of the four types of forest lands, indicating that the soil water content began to reach to saturation. Furthermore, the total runoff of the different types of vegetation, the runoff depth and the runoff coefficient were in the order of: E. ulmoides plantation > Pinus massoniana Lamb. forest > Sloping farmland > maple- Cinnamomum camphora (L.) J. Presl. mixed plantation. Additionally, under the same rainfall, there was a reduction in the runoff with an increase in the evaporation, and the total runoff of maple- $C$. camphora mixed plantation was the lowest.
\end{abstract}

\section{Introduction}

With the advent of the 21st century, the forest and water resources have become one of the most important resources and its scarcity is one of the major environmental problems faced by human beings. The complex relationship between the forests and water has always been a research hotspot in hydrology and ecology (Dong et al. 1987, Kong et al. 1990, Wei and Li 1997, Guo and Zhang 2001, Fan et al. 2003, Huang et al. 2007, Huang et al. 2018, Wang and Zhang 2009). Generally, the flow refers to the amount of water passing through a section of the river through a certain period of time. Runoff is important part of the water cycle in the forest ecosystems and its size directly reflects the comprehensive hydrological characteristics of the watershed. To measure the forest water conservation, maintaining water and soil by the forest, and reducing flood peaks runoff have been considered as an important indicator (Yu and Wang 1999). The forest surface runoff has caused a widespread attention in the academic circles. Swiss researchers believe that the forests have less impact on the surface runoff, while the Japanese and American scientists believe that forests reduce the surface runoff. In contrast, the Chinese researchers believe that forests increase the runoff. The size of the runoff is affected by the rainfall characteristics, vegetation conditions and topography (Ahmad-Shah and Rieley 1989, Potter et al. 1991, Schreiber 1996). Forest runoffs have been studied earlier for the Yunnan-Guizhou Plateau Qinling Mountains (Raat et al. 2002, Chuyong et al. 2004), the Greater Hinggan (Wallek et al. 2007) and Liupanshan area (Bellot and Escarre 1998). However, these researches were mostly concentrated in the large areas and large watersheds, and there were few studies on surface runoff in small watersheds. Thus in the present study four different vegetation types were selected, and the

*Author for correspondence: <clongsheng@ 163.com>. ${ }^{1}$ Hunan Cili Forest Ecosystem State Research Station, Cili, Hunan-427200, China. ${ }^{2}$ Qingyang Lake state-owned Forest Farm in Hunan province, Ningxiang410600, China. 
sloping farmland was used as a control to study the effects of forests on surface runoff through the regulation of runoff by different vegetation types in the small watershed of Wuling Mountain at West Hunan.

\section{Materials and Methods}

The research site was in the small watershed of the Nver Zhai in the Wuling mountain area, at West Hunan (E111 $\left.12^{\prime} 42.836^{\prime \prime}, \mathrm{N}^{\circ} 9^{\circ} 25^{\prime} 27.582^{\prime \prime}\right)$. It was located in the Liangxi Village, Lingyang Town, Cili County of Zhangjiajie City in Hunan Province of the People's Republic of China.The study area is situated about $7 \mathrm{~km}$ northwest of the urban area of Cili County. The watershed was relatively well-closed and is the secondary small tributary of Lishui. It is roughly north-south oriented and belongs to the low mountainous area of the Wuling Mountain. The total area of the watershed is $3.15 \mathrm{~km}^{2}$, the lowest elevation (at the exit of the main ditch) is $210 \mathrm{~m}$, and the highest elevation is $917.4 \mathrm{~m}$. The length of the main ditch is about $1.2 \mathrm{~km}$, and the main ditch vertical gradient is about $28.4 \%$ o. The forest coverage rate in this area is over $80 \%$, and the vegetation types are mainly forests returned from farmland and secondary forests. It is a concentrated area of forests returned from farmland. The soil-forming parent rock in this area is dominated by sand shale, and the soil is mainly yellow-red which is acid soil. The main vegetation types in the watershed are Pinus massoniana Lamb. forest, Eucommia ulmoides Oliv. plantation, Citrus reticulata Blanco and other miscellaneous forests. The research areas of this study are all located at the Hunan Cili Forest Ecosystem National Positioning Observation and Research Station.

The HOBO U30 automatic weather station was used to observe continuously the amount of rainfall and precipitation process from June 10, 2015 to September 10, 2016. At the same time, a siphon-type self-metering rain gauge and a standard rain gauge were used to determine the amount of rainfall and precipitation process outside the forest.

The surface runoff of each vegetation type was quantitatively measured using the slope runoff plot method. Three side-by-side slope runoff plots were set up in the Pinus massoniana forest, maple- Cinnamomum camphora (L.) J. Presl. mixed plantation and Eucommia ulmoides plantation, respectively. A slope runoff plot was set up in the sloping farmland as the control. Each plot had an area of $100 \mathrm{~m}^{2}$ and was surrounded by cement boundaries (Li et al. 2006). The runoff plot is shown in Fig. 1.

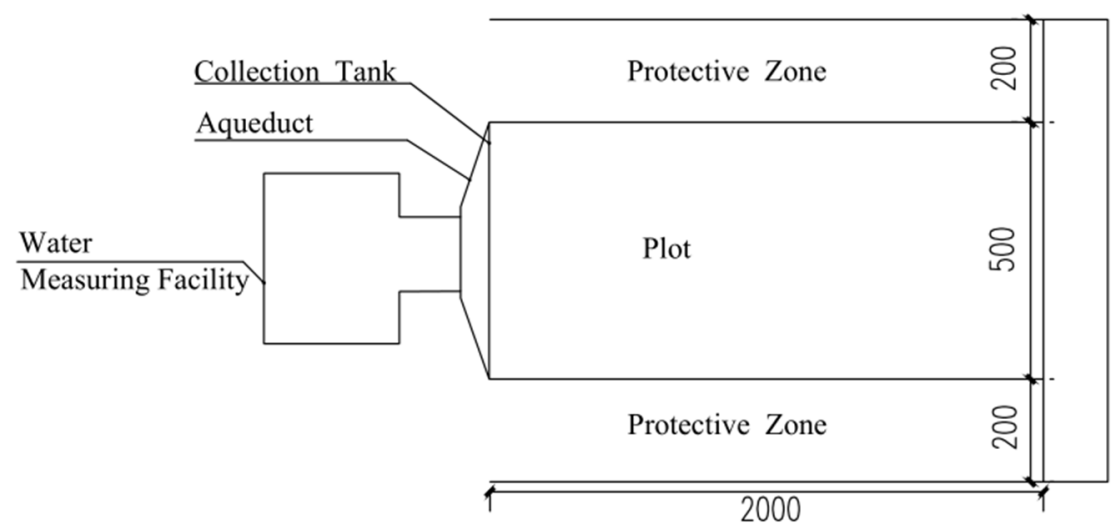

Fig. 1. Layout of the runoff plot (unit-cm).

Microsoft Excel and SPSS17.0 statistical analysis software were used for data processing and charting. 


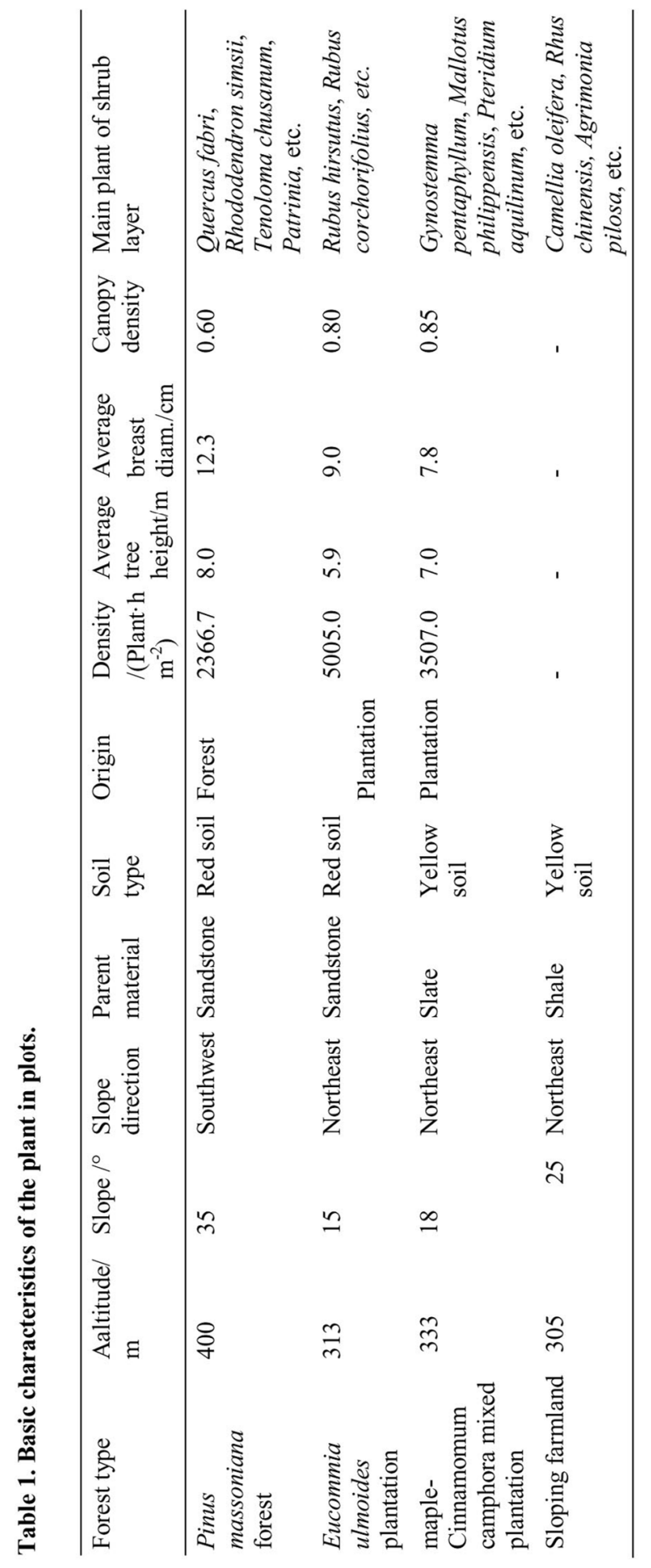




\section{Results and Discussion}

The rainfall in the research area reached $1971.80 \mathrm{~mm}$ during the observation period and there were 83 rainfalls during the study period (Table 2). Precipitation intensity refers to the amount of precipitation per unit time, the unit of which is $\mathrm{mm} / \mathrm{hrs}$ or $\mathrm{mm} / \mathrm{d}$. According to the standard regulated by the National Meteorological Administration, the rainfall can be classified into light rain $(0-10.0 \mathrm{~mm} / \mathrm{d})$, moderate rain $(10.1-20.0 \mathrm{~mm} / \mathrm{d})$, heavy rain $(20.1-50.0 \mathrm{~mm} / \mathrm{d})$, rainstorm $(50.1-100 \mathrm{~mm} / \mathrm{d})$, large rainstorm $(100.1-200.0 \mathrm{~mm} / \mathrm{d})$ and extra-large rainstorm (> 200.0 $\mathrm{mm} / \mathrm{d}$ ) based on the intensity of precipitation. In order to analyze the rainfall characteristics more scientifically, the rainfall during the study period was statistically analyzed according to rainfall intensity. Table 2 shows the distribution of the rainfall outside the forest during the observation period of the study area. There were 69 one-time rainfalls of $0.5-50 \mathrm{~mm} / \mathrm{d}$, accounting for $83.13 \%$ of the total number of rainfalls. Light rains were 37 times with less than $10 \mathrm{~mm} / \mathrm{d}$, which accounted for $44.58 \%$ of the total rainfall. The total rainfall of 37 light rains was $139.87 \mathrm{~mm}$, accounting for $7.09 \%$ of the total rainfall. Moderate rains $(10-25 \mathrm{~mm} / \mathrm{d})$ accounted for $20.03 \%$ of the total rainfall, and heavy rains $(25-50 \mathrm{~mm} / \mathrm{d})$ accounted for $27.16 \%$ of the total rainfall. However, the two types of rains only accounted for 27.71 and $18.07 \%$ of the total number of rains, respectively. There were 8 times of daily rainfalls of more than $50 \mathrm{~mm}$ of rainstorm and large rainstorm, which accounted for $9.64 \%$ of total number of rains. However, the total rainfall of these two types of rains was as high as $901.4944 \mathrm{~mm}$, accounting for $45.72 \%$ of the total rainfall. The moderate rain and heavy rain accounted for $45.78 \%$ of the total number of rains and the total rainfall was $930.48 \mathrm{~mm}$, accounting for $47.19 \%$ of the total rainfall. This indicates that the study area exhibited an abundant annual rainfall.

Table 2. Distribution of rainfall intensity outside forest during observation period.

\begin{tabular}{lcccccccc}
\hline Rainfall intensity & $0-0.5$ & $0.5-5$ & $5-10$ & $10-25$ & $25-50$ & $50-100$ & $>100$ & Total \\
\hline Number of rains & 6 & 20 & 11 & 23 & 15 & 3 & 5 & 83 \\
$\begin{array}{l}\text { Number ration of } \\
\text { rains (\%) }\end{array}$ & 7.23 & 24.10 & 13.25 & 27.71 & 18.07 & 3.61 & 6.02 & 100.00 \\
Rainfall & 1.83 & 49.46 & 88.59 & 394.95 & 535.53 & 175.09 & 726.40 & 1971.80 \\
Ratio of rainfall (\%) & 0.09 & 2.51 & 4.49 & 20.03 & 27.16 & 8.88 & 36.84 & 100.00 \\
\hline
\end{tabular}

The results preented in in Table 3 showed that as the rainfall increased, the surface runoff gradually increased, especially for the Eucommia ulmoides plantation land. When the rainfall was less than $10 \mathrm{~mm}$, the order of surface runoff was: sloping farmland > Pinus massoniana forest $>$ Eucommia ulmoides plantation > maple- Cinnamomum camphora mixed plantation. It was observed that when the rainfall was between 10 and $20 \mathrm{~mm}$, the order of surface runoff was: sloping farmland > Eucommia ulmoides plantation> Pinus massoniana forest > mapleCinnamomum camphora mixed plantation. When the rainfall was between 20 and $30 \mathrm{~mm}$, the order of surface runoff was: sloping farmland > Eucommia ulmoides plantation > Eucommia ulmoides plantation > Pinus massoniana forest > maple- Cinnamomum camphora mixed plantation. When the rainfall was between 30 and $40 \mathrm{~mm}$, the order of surface runoff was: Pinus massoniana forest > Eucommia ulmoides plantation > sloping farmland > maple-Cinnamomum camphora mixed plantation. Between 40 and $50 \mathrm{~mm}$ the rainfall, the order of surface runoff was: Eucommia ulmoides plantation > sloping farmland > Pinus massoniana forest > mapleCinnamomum camphora mixed plantation. When the rainfall was larger than $50 \mathrm{~mm}$, the order of 
surface runoff was: Eucommia ulmoides plantation > Pinus massoniana forest > sloping farmland > maple- Cinnamomum camphora mixed plantation. As the rainfall gradually increased to $30 \mathrm{~mm}$, the surface runoff of the sloping farmland remained the highest. This might be due to the destruction of the sloping land by human activities. In addition, there was a little surface coverage and the soil was hard, which added the difficulty for water to penetrate the soil. As a result, most of water was turned into the surface runoff and they run into the river. This shows from another aspect that there was a serious issue of soil erosion of the sloping farmland. When rainfall was more than $50 \mathrm{~mm}$, there was a significant augment in the surface runoff of the four types of forest land, indicating that the soil water content began to reach saturation. From the perspective of vegetation types during the observation period, the surface runoff was ranked as Eucommia ulmoides plantation $\left(68.30 \mathrm{~m}^{3}\right)>$ Pinus massoniana forest $\left(51.01 \mathrm{~m}^{3}\right)>$ Sloping farmland $\left(41.34 \mathrm{~m}^{3}\right)>$ Maple- Cinnamomum camphora mixed plantation $\left(2.36 \mathrm{~m}^{3}\right)$. Great differences among the surface runoff of these 4 different types of forest land due to different forest crown, woodland litter, soil microorganism, duration of sunny and rainy days, etc. were observed The surface runoff of the newly-created forest land with small crown and fewer woodland litter was larger than that of a forest with larger crown, higher canopy density and abundant woodland litter.

Table 3. Runoff distribution of different stand types during observation period.

\begin{tabular}{lcccc}
\hline $\begin{array}{l}\text { Rainfall } \\
\text { interval }\end{array}$ & $\begin{array}{c}\text { Pinus massoniana } \\
\text { forest }\end{array}$ & $\begin{array}{c}\text { Eucommia ulmoides } \\
\text { plantation }\end{array}$ & $\begin{array}{c}\text { Maple- Cinnamomum- } \\
\text { camphora } \text { mixed plantation }\end{array}$ & $\begin{array}{c}\text { Sloping } \\
\text { farmland }\end{array}$ \\
\hline$<10 \mathrm{~mm}$ & 0.35 & 0.17 & 0.03 & 0.7 \\
$10-20 \mathrm{~mm}$ & 0.55 & 0.57 & 0.12 & 1.2 \\
$20-30 \mathrm{~mm}$ & 0.65 & 0.79 & 0.19 & 1.55 \\
$30-40 \mathrm{~mm}$ & 0.27 & 0.13 & 0.04 & 0.1 \\
$40-50 \mathrm{~mm}$ & 2.69 & 3.64 & 0.20 & 2.7 \\
$\geq 50 \mathrm{~mm}$ & 46.50 & 63.00 & 1.79 & 35.09 \\
Total & 51.01 & 68.30 & 2.36 & 41.34 \\
\hline
\end{tabular}

The annual runoff characteristics of different vegetation types are shown in Table 4. In the three runoff fields of Pinus massoniana forest, the runoff was between 47.34 and $58.24 \mathrm{~m}^{3}$. The surface runoff of Eucommia ulmoides plantation was $55.15 \sim 75.35 \mathrm{~m}^{3}$, and those of mapleCinnamomum camphora mixed plantation and sloping farmland were $1.47 \sim 2.96 \mathrm{~m}^{3}$ and $41.34 \mathrm{~m}^{3}$, respectively. The runoff depths of the different vegetation types were ranked in the order of: Eucommia ulmoides plantation $(6.83 \mathrm{~mm})>$ Pinus massoniana forest $(5.10 \mathrm{~mm})>$ Slope farmland $(4.13 \mathrm{~mm})>$ maple- Cinnamomum camphora mixed plantation $(0.24 \mathrm{~mm})$. The runoff coefficient was ranked as Eucommia ulmoides plantation $(0.35 \%)>$ Pinus massoniana forest $(0.26 \%)>$ Sloping farmland $(0.21 \%)>$ Maple- Cinnamomum camphora mixed plantation $(0.012 \%)$. Runoff is the difference between rainfall and evaporation. Therefore, the size of the runoff is related not only to the rainfall but also to the evaporation. Under the same rainfall, the larger the evaporation, the smaller was the runoff. In this study, the annual average runoff of the Eucommia ulmoides plantation was the highest, indicating that the evaporation of Eucommia ulmoides plantation was least. On the other hand, the total amount of runoff in the maple- Cinnamomum camphora mixed plantation was the lowest, indicating that the maple-Cinnamomum camphora mixed plantation had the highest evaporation. The runoff of the maple- Cinnamomum camphora mixed plantation 
differed from that of Eucommia ulmoides plantation by 24.94 times, indicating that the soil and water loss of the maple- Cinnamomum camphora mixed plantation was little and it exhibited to maintain soil and water and retain soil. This is because the maple- Cinnamomum camphora mixed plantation is a broad-leaved forest, has a larger crown and thus receives more direct sunlight from outside. It addition, it has more ground coverage, which helps to hold the water. The presence of forest vegetation helps to slow the formation of runoff. Forest vegetation increases the roughness of the surface, making it difficult for the rain to form a rapid runoff in a short period of time, thus reducing the direct erosion of the surface. From the above analysis, it can be seen that the surface runoff of the maple- Cinnamomum camphora mixed plantation was the least, indicating that the maple- Cinnamomum camphora mixed plantation has a strong soil and water retention capacity. This might be on one hand, is due to the better growth of the maple-Cinnamomum camphora mixed plantation and its root system, on the other hand, there exists a thick layer of woodland litter in the maple- Cinnamomum camphora mixed plantation. The litter helps to retain the rainfall, which slows down the flow of water to the surface and thus protects the soil and water.

Table 4. Annual runoff characteristics of different vegetation types.

\begin{tabular}{|c|c|c|c|c|c|}
\hline $\begin{array}{l}\text { Runoff field } \\
\text { number }\end{array}$ & Vegetation types & $\begin{array}{c}\text { Rainfall } \\
(\mathrm{mm})\end{array}$ & $\begin{array}{l}\text { Total runoff } \\
\qquad\left(\mathrm{m}^{3}\right)\end{array}$ & $\begin{array}{l}\text { Runoff depth } \\
(\mathrm{mm})\end{array}$ & $\begin{array}{c}\text { Runoff } \\
\text { coefficient }(\%)\end{array}$ \\
\hline 1 & Pinus massoniana forest & 1971.80 & 47.34 & 4.734 & 0.24 \\
\hline 2 & Pinus massonian forest & 1971.80 & 47.45 & 4.745 & 0.24 \\
\hline 3 & Pinus massonian forest & 1971.80 & 58.24 & 5.824 & 0.30 \\
\hline \multicolumn{2}{|l|}{ Average value } & 1971.80 & 51.01 & 5.10 & 0.26 \\
\hline 4 & $\begin{array}{l}\text { Eucommia ulmoides } \\
\text { plantation }\end{array}$ & 1971.80 & 55.15 & 5.515 & 0.28 \\
\hline 5 & $\begin{array}{l}\text { Eucommia ulmoides } \\
\text { plantation }\end{array}$ & 1971.80 & 75.35 & 7.535 & 0.38 \\
\hline 6 & $\begin{array}{l}\text { Eucommia ulmoides } \\
\text { plantation }\end{array}$ & 1971.80 & 74.40 & 7.44 & 0.38 \\
\hline \multicolumn{2}{|l|}{ Average value } & 1971.80 & 68.30 & 6.83 & 0.35 \\
\hline 7 & $\begin{array}{l}\text { Maple- Cinnamomum- } \\
\text { camphoramixed plantation }\end{array}$ & 1971.80 & 1.47 & 0.147 & 0.008 \\
\hline 8 & $\begin{array}{l}\text { Maple- Cinnamomum- } \\
\text { camphora mixed plantation }\end{array}$ & 1971.80 & 2.66 & 0.266 & 0.014 \\
\hline 9 & $\begin{array}{l}\text { Maple- Cinnamomum- } \\
\text { camphora mixed plantation }\end{array}$ & 1971.80 & 2.96 & 0.296 & 0.015 \\
\hline \multicolumn{2}{|l|}{ Average value } & 1971.80 & 2.36 & 0.24 & 0.012 \\
\hline 10 & Sloping farmland & 1971.80 & 41.34 & 4.13 & 0.21 \\
\hline
\end{tabular}

In this table the Runoff depth $(\mathrm{mm})=$ runoff $\left(\mathrm{m}^{3}\right) /$ study plot area $\left(\mathrm{m}^{2}\right) * 10$. Runoff coefficient $=$ runoff depth / rainfall $* 100 \%$

The relationship between the surface runoff and rainfall for different vegetation types presented in Fig. 2 shows that the surface runoff of different vegetation types increased with the increase in rainfall, and the surface runoff had a significant linear relationship with the rainfall, with the $\mathrm{R}^{2}$ values for all greater than 0.82 . The surface runoff and rainfall of different vegetation 
types had the relationship of $\mathrm{y}=\mathrm{ax}-\mathrm{b}$. $\mathrm{y}$ represents the surface runoff, and $\mathrm{x}$ represents the rainfall. For Pinus massoniana forest, $\mathrm{y}=0.617 \mathrm{x}-5.003\left(\mathrm{R}^{2}=0.8405\right)$. For Eucommia ulmoides plantation, $\mathrm{y}=0.6408 \mathrm{x}-4.7895\left(\mathrm{R}^{2}=0.8293\right)$. For maple- Cinnamomum camphora mixed plantation, $\mathrm{y}=0.0557 \mathrm{x}-0.7193\left(\mathrm{R}^{2}=0.9158\right)$. For sloping farmland, $\mathrm{y}=0.5458 \mathrm{x}-4.8453\left(\mathrm{R}^{2}=\right.$ 0.8792). Considering Pinus massoniana forest case as an example; when the rainfall was $206 \mathrm{~mm}$, the corresponding surface runoff reached the maximum of $95.36 \mathrm{~m}^{3}$. When the rainfall was 0.88 $\mathrm{mm}$, the corresponding surface runoff was only $0.10 \mathrm{~m}^{3}$. Similarly, the sloping farmland showed the same pattern as the forest land. When the rainfall reached maxima (206 $\mathrm{mm})$, the corresponding surface runoff also reached the maxima of $87.58 \mathrm{~m}^{3}$. When the rainfall was 0.88 $\mathrm{mm}$, the corresponding surface runoff was only $0.14 \mathrm{~m}^{3}$. The Eucommia ulmoides plantation and maple- Cinnamomum camphora mixed plantation also showed variation pattern consistent with that of Pinus massoniana forest and sloping farmland. This indicates that the greater the rainfall, the greater is the surface runoff of different vegetation types. The might be due to highest rainfall forms a flush on the surface, and when the soil retention capacity of the surface reaches the limit, the runoff is formed. The maple- Cinnamomum camphora mixed plantation of different tree types had the smallest surface runoff, indicating that there were more litters on the ground surface, and the soil permeability and infiltration capacity of the forest land was stronger. In contrast, the surface of the sloping farmland was smooth due to the severe disturbances caused by humans. Under the scouring of long-term rainfall, the water cannot penetrate quickly, thus forms a large runoff, which is not conducive to soil and water conservation.
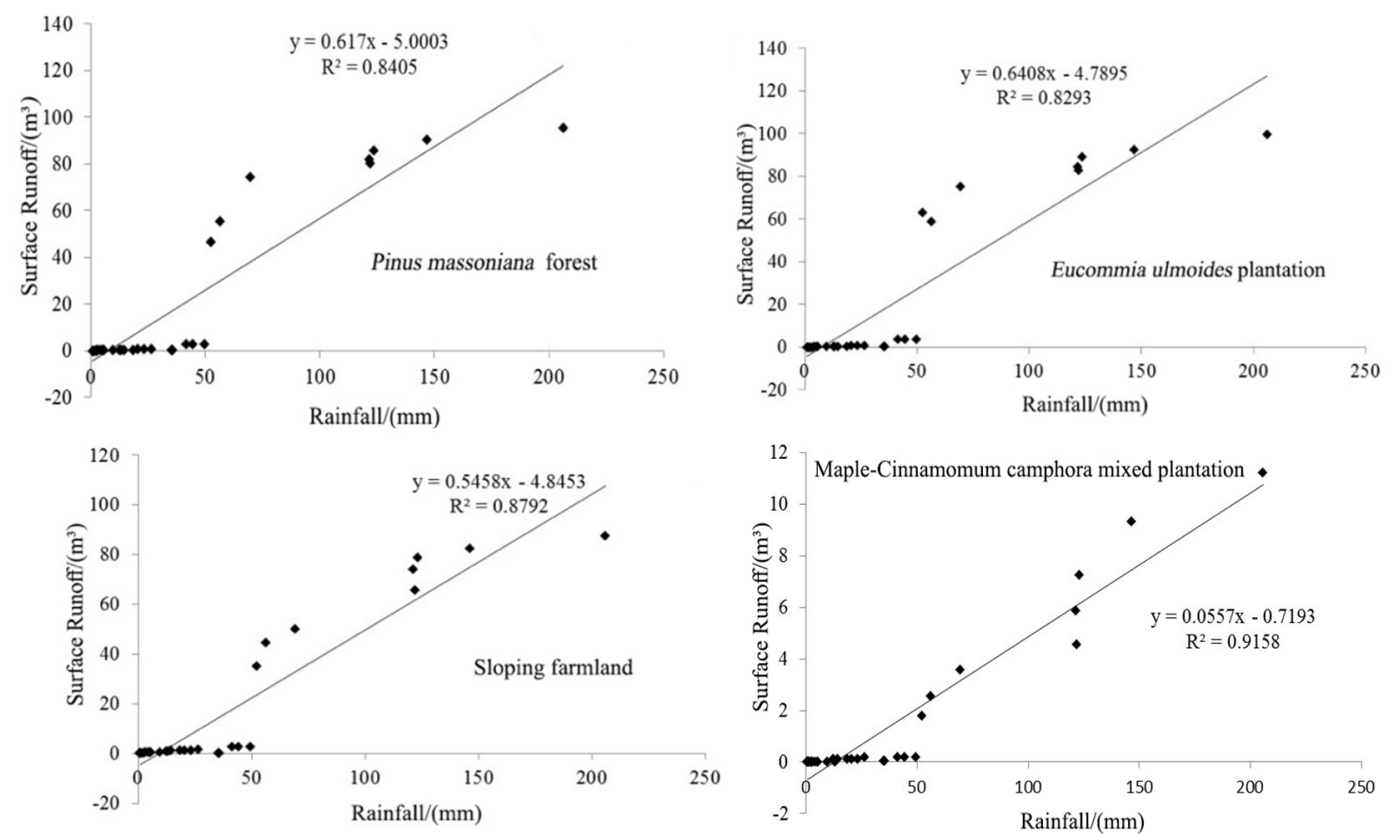

Fig. 2.Relationship between surface runoff and rainfall for different vegetation types.

From June 10, 2015 to September 10, 2016, the rainfall reached $1971.80 \mathrm{~mm}$ and there 83 rainfalls occurred in the study period. From the one-time rainfall situation, there were 69 one-time rainfalls of $0.5-50 \mathrm{~mm} / \mathrm{d}$, accounting for $83.13 \%$ of the total number of rains. There were 37 times of light rains with less than $10 \mathrm{~mm} / \mathrm{d}$, accounting for $44.58 \%$ of the total rains. The total rainfall of 
light rain was $139.87 \mathrm{~mm}$, accounting for $7.09 \%$ of the total rainfall. Moderate rain $(10-25 \mathrm{~mm} / \mathrm{d})$ accounted for $20.03 \%$ of total rainfall, and heavy rain $(25-50 \mathrm{~mm} / \mathrm{d})$ accounted for $27.16 \%$ of total rainfall. The moderate rain and heavy rain accounted for $45.78 \%$ of the total number of rain, and their total rainfall was $930.48 \mathrm{~mm}$, accounting for $47.19 \%$ of the total rainfall. This indicated that the annual rainfall in the study area was abundant.

As the rainfall increased, the surface runoff gradually increased; especially for the Eucommia ulmoides plantation land. When the rainfall gradually increased to $30 \mathrm{~mm}$, the surface runoff of the sloping farmland remained the highest. When the rainfall was larger or equal to $50 \mathrm{~mm}$, there was a significant increase in the surface runoff of the four types of forest land, indicating that the soil began to reach saturation. The total runoff, runoff depth and runoff coefficient of different vegetation types were different, and the magnitude of the order was Eucommia ulmoides plantation >Pinus massoniana forest > sloping farmland > maple- Cinnamomum camphora mixed plantation. This was mainly due to the differences in the soil conditions, vegetation conditions, roots and other conditions of different vsegetation types, which led to the varied influences on the surface runoff (Lü et al. 2015). Under the same rainfall, the larger the evaporation, the lower was the runoff. The total amount of runoff in the maple- Cinnamomum camphora mixed plantation was the lowest, indicating that the maple- Cinnamomum camphora mixed plantation exhibited a highest evaporation. The surface runoff of different vegetation types increased with the increase of rainfall, and the surface runoff showed an apparent linear relationship with rainfall, which is consistent with the results reported by Huang and Wei (1991), Sisay (2017)

From the investigation it may be inferred that under the same rainfall, the runoff pattern was indirectly related to evaporation. Annual average runoff of the Eucommia ulmoides plantation was the largest, indicating that the evaporation of the same plantation was least. On the other hand, the total amount of runoff in the maple-Cinnamomum camphora mixed plantation was the smallest, indicating that this plantation had the highest evaporation. The runoff of the maple- Cinnamomum camphora mixed plantation differed from that of Eucommia ulmoides plantation by 24.94 times, indicating that the soil and water loss of the maple-Cinnamomum camphora mixed plantation was lower and it exhibited to maintain soil and water and retain soil. The reason is that this forest is composed of broad-leaved trees which has a larger crown and thus receives more direct sunlight from outside. In addition, it has more ground coverage, which helps to hold the water. The presence of forest vegetation helps to slow the formation of runoff. Forest vegetation increases the roughness of the surface, making it difficult for the rain to form a rapid runoff in a short period of time, thus reducing the direct erosion of the surface. In addition, it may be concluded that the least surface runoff of the maple- Cinnamomum camphora mixed plantation provides a strong soil and water retention capacity in this forest because of its mixed plantation, its root system. There exists a thick layer of woodland litter in this mixed plantation and the litter helps to retain the rainfall, which slows down the flow of water to the surface and thus protects the soil and water.

\section{Acknowledgements}

This work was supported by the grant of Forestry Science and Technology Plan Project in Hunan (XLC201701-2), Major Research and Development Program in Hunan (2017NK2223), Forestry Science and Technology Plan Project in Hunan (XKL201704, XLKPT201703, XLKPT201706, XLKPT201707, XLKPT201710, HNGYL-2020-01, HNGYL-2019-01), National Science and Technology Plan for Twelfth Five-Year in the Countryside (2015BAD07B04), National Key R \& D Program of China (2017YFC0505506), and Forestry Science and Technology Project in Hunan (2012-HNLYKY-01). 


\section{References}

Ahmad-Shah A and Rieley JO 1989. Influence of tree canopies on the quantity of water and amount of chemical elements reaching the peat surface of a basin mire in the midlands of England. J. Ecol. 77(2): 357-370.

Bellot J and Escarre A 1998. Stemflow and throughfall determination in a resprouted Mediterranean holmoak forest. Annales Des Sci. Foresti. 55: 847-865.

Chuyong GB, Newbery DM and Songwe NC2004. Rainfall input, throughfall and stemflow of nutrients in a central African rain forest dominated by ectomycorrhizal trees. Biogeochemist 67(1): 73-91.

Dong SR, Guo JT and Man RZ 1987. Throughfall, stemflow and canopy interception in a pinus tabulaeformis plantation of north China. J. Beijing Forest. Univ. 9(1): 58-68.

Fan SX, Jiang DM and Alamusa 2003. Studies on throughfall model in forest area. Chinese J. Ecol. 7: 14031407.

Guo QR and Zhang BG 2001. Mathematical Model and Dynamic Characteristic of Rainfall-infiltration-runoff of Latored Soils in Hills. J. Soil Water Conserv. 15(1): 62-65.

Huang CB and Wei BE 1991. A Study on Surface Runoff of Different Types of Vegetation in Guangxi Autonomous region. Forest. Sci. 27(5): 490-497.

Huang TC, He KN and Wang XB 2018. Relationship between Railfall Redistribution and Canop Structure of Betula platyphylla Canopy in Datong, Qinghai. J. Northwest Forest. Univ. 33(3): 1-6.

Huang ZG, Li FR and Cao Y 2007. Ecological Benefit of Soil and Water Conservation of Eucommia ulmoides and Vernica fordii Plantation in Hilly Red Soil Region, Southern China. Forest. Sci. 8: 8-14.

Kong FZ, Song B and Yan TF 1990. Modelling on the relationship between rainfall and interception of forest canopy. Chinese J. Appl. Ecol. 3: 201-208.

Li XQ, Tian YX and Tao JL 2006. Design and layout of benefit monitoring for returning farmland to forest project in Hunan Province. Hunan Forest. Sci. Technol. 33(2): 24-37.

Lü XZ, Kang LL and Zuo ZG 2015. Characteristics of Slope Runoff under Different Vegetation Conditions in Lvergou Watershed of the Loess Plateau. Chinese J. Eco-Environ. 24(7): 1113-1117.

Potter CS, Ragsdale HL and Swank WT 1991. Atmospheric deposition and foliar leaching in a regenerating southern appalachian forest canopy. J. Ecol. 79: 97-115.

Raat KJ, Draaijers G and Schaa PMG 2002. Spatial variability of throughfall water and chemistry and forest floor water content in a Douglas fir forest stand. Hydrology and Earth Sys. Sci. 6(3): 363-374.

Schreiber L 1996. Wetting of the upper needle surface of Abies grandis influence of $\mathrm{pH}$, wax chemistry and epiphyllic microflora on contact angles. Plant, Cell and Environ. 19: 455-463.

Sisay M 2017. Review on the Role of Forest Landscapes in Watershed Hydrologic Processes. J. Environ. Earth Sci. 7(11): 97-104.

Wallek W, Hofmann J and Feller IC 2007. Canopy interactions of rainfall in an off-shore mangrove ecosystem dominated by Rhizophora, angle (Belize). J. Hydrol. 345(1-2): 70-79.

Wang AJ and Zhang WB 2009. Reviews of Vagetation Interception of Rainfall. Res. Soil and Water Conserv. 4: 55-59.

Wei ZX and Li SH 1997. Study on the Characteristics of Rainfall Interception in Different Forest Lands. China Soil and Water Conserv. 5: 23-25.

Yu ZM and Wang LX 1999. Research on Benefits of Water Conservation Forests. Beijing: China Forestry Publishing House.

(Manuscript received on 12 April, 2019; revised on 24 March, 2021) 